\title{
Vývoj podzemního odtoku z části Českomoravské vrchoviny
}

\section{RADEK CHMELAR̆}

Klíčová slova: podzemní voda - podzemní odtok - doplňování podzemních vod - Českomoravská vrchovina

\section{SOUHRN}

Článek se zabývá vývojem podzemního odtoku z části Českomoravské vrchoviny. Jedná se o téma aktuální a vzhledem $\mathrm{k}$ současné situaci také často diskutované. Problematika podzemních vod a jejich doplňování je zásadním (nejen) hydrogeologickým problémem, jelikož nepríznivé klimatické podmínky v posledních letech, a to zejména nízké srážkové úhrny, mají negativní vliv na doplňování podzemních vod a dochází ke snižování jejich hladin. Aby mohl být tento stav i vývoj exaktně posouzen, byly vypočteny hodnoty podzemního odtoku a doplňování podzemních vod v letech 2006-2015 z vybrané části Českomoravské vrchoviny v blízkosti Nového Města na Moravě. Jelikož v této konkrétní oblasti nebyly provedeny téměř žádné výzkumy tohoto charakteru, výsledky bude možné použít i pro prípadné další výzkumy. Získaná data taktéž pomohou přibližit stav a vývoj doplňování podzemních vod v těchto letech pro zájmovou oblast. Výsledné hodnoty umožnily především zjistit trend a vývoj podzemního odtoku v dané oblasti a získat hodnoty, které umožní porovnání s jinými oblastmi. Výpočty byly uskutečněny aplikací Mailletovy rovnice a hydrogeologického programu PART na data získaná od ČHMÚ (denní průtoky v toku a týdenní vydatnosti pramene v letech 2006-2015). Stručně bylo nutné také popsat geomorfologii, klimatické podmínky, geologii a hydrologii zájmové oblasti (obr. 1).

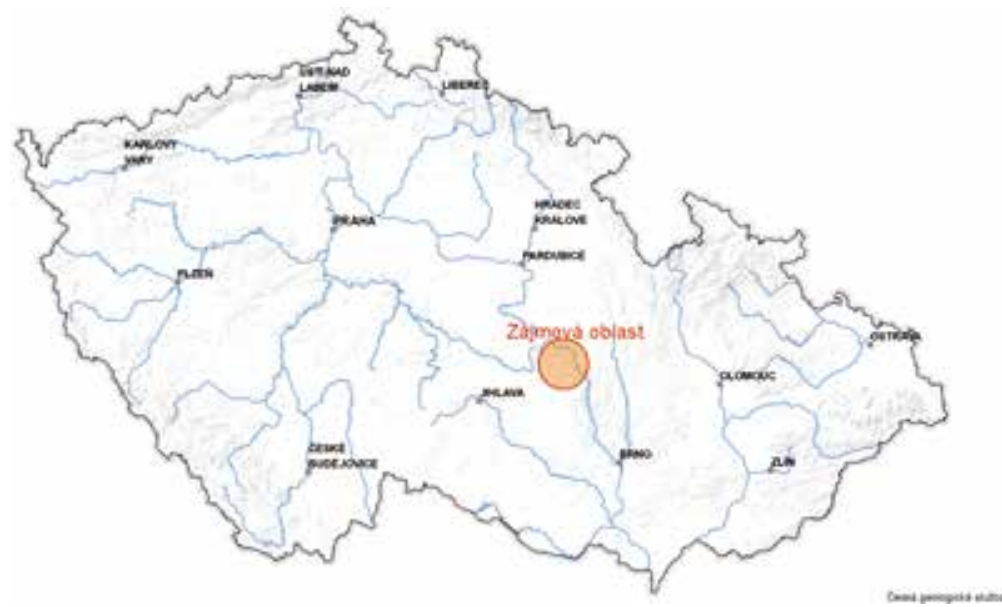

Obr. 1. Príbližné vymezení zájmové oblasti (zdroj: Česká geologická služba, mapová aplikace: geovědní mapa 1: 500 000, dostupné z: https://mapy.geology.cz/geocr500/, upraveno)

Fig. 1. Approximate location of interest area

\section{ÚVOD}

Článek je zaměřen na problematiku podzemních vod a doplňování jejich zásob. Jedná se o často řešené téma, jelikož nepř́iznivé klimatické podmínky, které panují v posledních letech, a to především nízké srážkové úhrny, zvyšující se teploty a z toho plynoucí sucho, mají nepríznivý vliv na doplňování zásob podzemních vod. Klimatické změny ve střední Evropě jsou charakteristické obdobími sucha $v$ letních měsících, $v$ zimních měsících dochází $\mathrm{k}$ redukci srážek a dočasné akumulaci vody ve formě sněhu [1]. Hladiny podzemních vod se neustále snižují. Pro analýzu vývoje podzemního odtoku v této oblasti byla použita data o denních průtocích na řece Fryšávce a data o týdenních vydatnostech pramene PB0286 Ski I, Nové Město na Moravě, zájmová oblast se nachází v jihovýchodním okraji CHKO Ždárské vrchy. Geograficky náleží obě povodí geomorfologickému okrsku Pohledeckoskalská vrchovina, podcelku Ždárské vrchy, celku Hornosvratecká vrchovina. Povodí pramene PB0286 se nachází v nadmořské výšce zhruba 635-650 m n. m., cca 2 km severně od centra Nového Města na Moravě a přibližně 300 m od hlavní části Vysočina Arény. Pramen Fryšávky vyvěrá na povrch v nadmořské výšce cca $750 \mathrm{~m}$ n. m., zhruba 1,5km severozápadně od obce Tři Studně, jeho tok pak pokračuje do nižších nadmořských výšek a končí zhruba v $500 \mathrm{~m}$ n. m. v obci Jimramov. Měřicí bod průtoku se nachází zhruba na pátém kilometru toku, jedná se o stanici Kadov-Fryšava (výpočty byly uskutečněny jen pro část povodí po tuto stanici ČHMú). Tyto dva měřicí body (obr. 2) jsou od sebe vzdáleny zhruba 5 km. Výsledné hodnoty podzemního odtoku získané pro tyto povodí byly využity k analyzování a posouzení vývoje doplňování podzemních vod v této oblasti.

$\checkmark$ tomto článku se taktéž vyskytuje termín efektivní infiltrace, který lze považovat za synonymum podzemního odtoku, avšak jen $v$ prípadě, kdy $\vee$ povodí nedochází k výrazným, především antropogenním, odběrưm či prírůstkům vod. Termín efektivní infiltrace tedy nelze použít u pramene PB0286, jelikož $\checkmark$ jeho povodí dochází v zimních měsících k zasněžování, což je způsobeno polohou povodí v JV části Vysočina Arény (vlastníkům byla dokonce uložena pokuta za nadměrné čerpání vod pro zasněžování z blízkého Cihelského potoka). Geologicky se obě povodí nachází velmi blízko rozhraní mezi strážeckým moldanubikem a svrateckým krystalinikem, jedná se tedy o puklinové prostředí, kde jsou infiltrace a proudění podzemních vod vázány na pukliny, trhliny a zlomy. Proudění mělkých podzemních vod je $v$ tomto prostředí vázáno jen na málo vyvinutý kvartérní pokryv, hlubší oběh pak na puklinovou propustnost horninového masívu [2]. Pro obě oblasti jsou charakteristické katazonálně až ultrametamorfované horniny, především pararuly, ortoruly, migmatitizované ortotuly až migmatity. $V$ oblasti povodí pramene se jedná především o ortoruly až migmatity reprezentující gfohlskou skupinu moldanubika. Místy se zde nachází i biotitické migmatity (tzv. arterity). Jednotka strážeckého moldanubika je rozdělena na dvě dílči části křídelským zlomem, probíhajícím zhruba v linii 


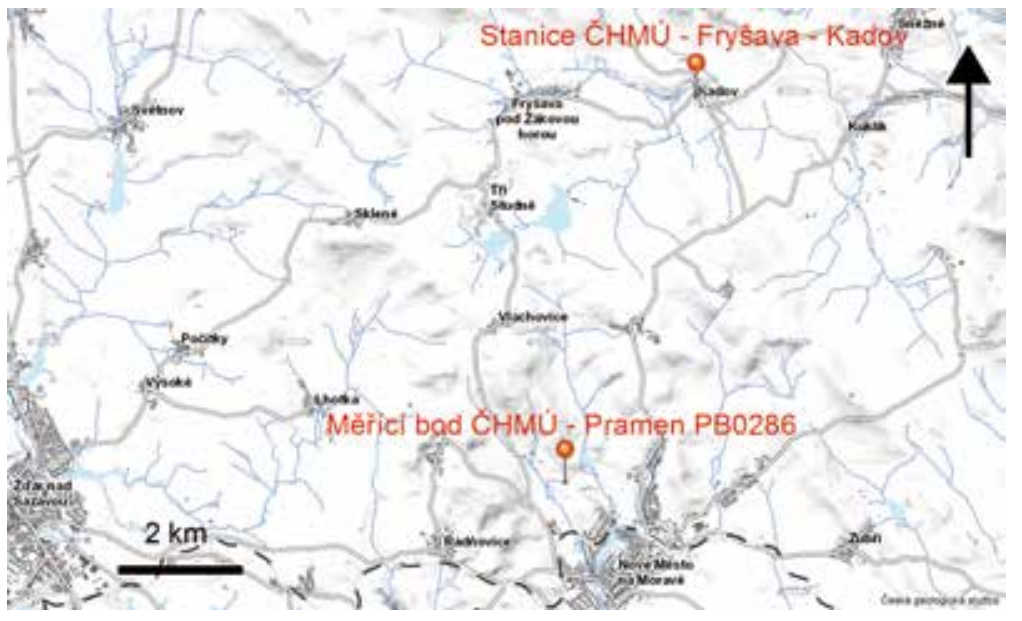

Obr. 2. Poloha meřicích bodů ČHMÚ (zdroj: Česká geologická služba, mapová aplikace: geovědní mapa 1:500 000, dostupné z: https://mapy.geology.cz/geocr500/, upraveno) Fig. 2. Location of measuring points of $\mathrm{CHMl}$

Bystřice n. P. - Nové Město na Mor. - Poříčí. Zkoumanou částí povodí Fryšávky se táhne menší zlom kadovský, který má směr SZ-JV [3]. Tyto především příčné zlomy jsou velmi důležité, protože umožňují poměrně rychlou infiltraci vody do horninového prostředí. Podzemní voda může díky těmto dislokacím proudit na vzdálenost až několika kilometrů [4].

\section{METODIKA}

Podzemní odtok (někdy nazývaný jako základní) představuje tu část vod, která se infiltrovala do pásma nasycení, ze kterého následně odtéká do určitého profilu povrchových vod. K vyhodnocení podzemního odtoku u pramene PB0286 byla použita Mailletova rovnice [5]. Pro výpočet bylo nutné znát plochu povodí pramene a hodnoty vydatnosti pramene. Stanovení přesné plochy drenážní oblasti pro pramen PB0286 bylo obtížnější, zejména kvưli její malé ploše. Po detailním prozkoumání oblasti byla plocha stanovena na zhruba 0,015 km². Tento pramen je monitorován ČHMÚ jednou za týden za pomocí trojúhelníkového měrného přelivu. Hodnoty vydatnosti jsou udávány v I/s. Výpočet podzemního odtoku pro povodí Fryšávky byl uskutečněn ve specializovaném hydrogeologickém programu PART, který vypočitává hodnoty podzemního odtoku díky hodnotám průtoků a velikosti drenážní oblasti zkoumané části toku. Použita byla data o denních průtocích ve vodoměrné stanici Kadov-Fryšava spadající pod ČHMú. Zkoumaná část povodí Fryšávky má plochu o velikosti 20,93 km². Použita byla data za roky 2006-2015.

Nejprve bylo nutné získat hodnoty průtoků ze zkoumané části toku Fryšávky a hodnoty vydatností pramene PB0286. Tato data byla zakoupena od ČHMÚ, který poskytl denní hodnoty pro Fryšávku $\left(\mathrm{v} \mathrm{m}^{3} / \mathrm{s}\right)$ a týdenní hodnoty pro pramen PB0286 ( $\mathrm{v} \mathrm{l} / \mathrm{s})$. Hodnoty bylo následně nutné upravit do správné podoby $\checkmark$ textovém editoru, jelikož program PART pracuje jen s přesně upravenými a správně prevedenými daty. $U$ hodnot průtoků bylo nutné hodnoty převést do jednotek, které se používají v USA, jelikož použitý program byl vytvořen americkými hydrogeology. Po vložení dat do príkazového rádku programu podle návodu poskytl program PART výsledky ve čtyřech různých podobách $\checkmark$ textovém dokumentu, a to výsledky denní, měsíční (obr. 3), čtvrtletní a roční. Hodnoty byly následně zpracovány do přehledných grafư. Ještě předtím však bylo opět nutné převést hodnoty zpět do naší metrické soustavy.

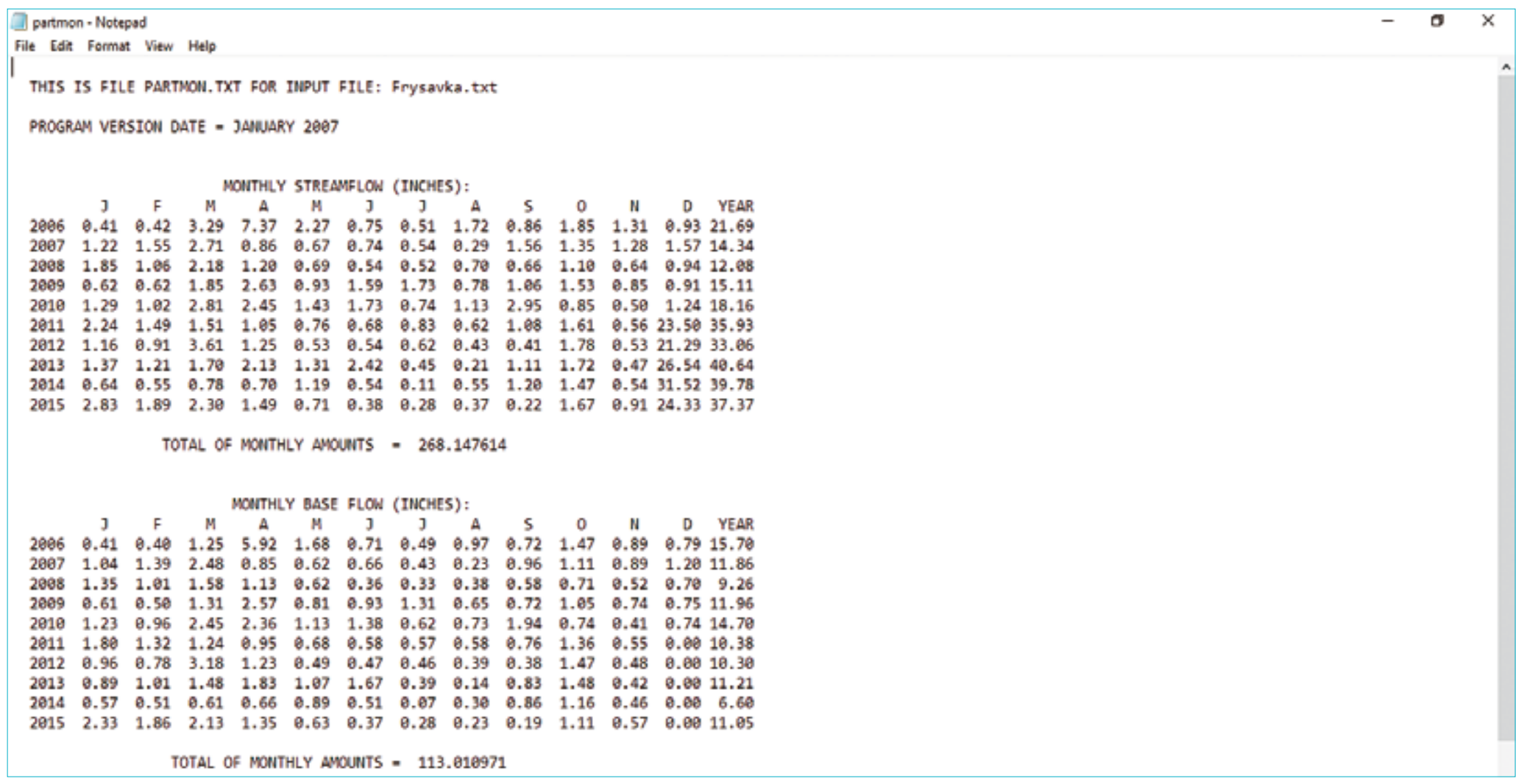

Obr. 3. Ukázka výstupu z programu PART, měsíční hodnoty podzemního odtoku pro Fryšávku

Fig. 3. Output from PART, monthly values 
Výpočty pro pramen PB0286 byly méně složité, nebylo nutné převádět jednotky, jelikož výpočty byly uskutečněny $v$ programu vytvořeném $v$ Excelu, který navíc vytvořil grafy vývoje výsledných hodnot. Tento program využívá Mailletovu rovnici [5].

Metoda získávající hodnoty podzemního odtoku na základě průtokového hydrografu, tedy záznamu průtoku v toku za určité období, by měla být ve většině prípadů použita pro dlouhou dobu záznamu (rok nebo více), aby byl získán přesný odhad průměrného odtoku podzemní vody. V př́ipadě, že je doba analýzy dostatečně dlouhá, aby bylo možné zanedbat efekt na vodní bilanci ve změnách zásob, podzemní odtok se dá považovat za efektivní infiltraci. Ve většině prípadů se dá tato metoda rozdělit na dva základní kroky: 1. stanovení období zanedbatelného povrchového odtoku a určení podmínky, kdy doplňování podzemní vody je rovno průtoku v toku, a 2. interpolace doplňování podzemních vod ve dnech mezi těmito obdobími. Pro dané dny je požadavek předcházející recese splněn, pokud recese byla kontinuální po dobu N dní nebo více předcházejících dní [6] (tuto metodu využívá i program PART).

\section{PROGRAM PART}

Jedná se o automatizovaný počítačový program, který byl vytvořen na základě modelu vyvinutého Rorabaughem [7]. Je založen na predchozí recesi průtokových hodnot, tedy na snižování průtoku po srážkové události. Program využivá rozdělení průtoku pro odhad denního záznamu podzemního odtoku. Zachycuje období záznamu pro dny, které odpovídají požadavkům předchozí recese, infiltrace podzemní vody je $v$ těchto dnech rovna průtoku. Poté se lineárně interpoluje odtok podzemních vod ve dnech, které neodpovídají požadavkům na předchozí recesi [7]. Program PART je určen pro analýzu systému proudění podzemní vody, který je charakterizován doplňováním difuzního prostoru na vodní plochu a odtokem podzemní vody do proudu. Metoda je vhodná, pokud se celá část nebo většina podzemní vody v povodí dostává do toku. Počitá s tím, že podzemní odtok můžeme brát jako průtok v toku po určitém čase od srážkové události [8] podle následující rovnice:

$$
N=A^{0,2}
$$

kde $\quad N \quad$ je počet dnů od srážkové události,

A plocha povodí (ve čtverečních mílích).

\section{MAILLETOVA ROVNICE}

Slouží k výpočtu podzemního odtoku z hodnot vydatností pramene (popř. toku), navazuje na rovnici Boussinesqua [9] a vypadá takto:

$$
Q_{t}=Q_{0} \cdot e^{(-a t)}
$$

kde $Q_{t} \quad$ je vydatnost při období vyprazdňování (recese) vody v čase $t_{\text {, }}$

$$
\mathrm{Q}_{0} \quad \text { vydatnost } \mathrm{v} \text { čase } t=0 \text {, }
$$

a recesní koeficient.

Tato rovnice je charakterizována exponenciálním tvarem, který počítá s lineárním vztahem mezi hladinou podzemních vod a průtokem. Nejprve je však nutné vypočitat recesní koeficient alfa, který vyjadřuje sklon hodnot recese, a k jeho výpočtu může být použita tato rovnice [6]

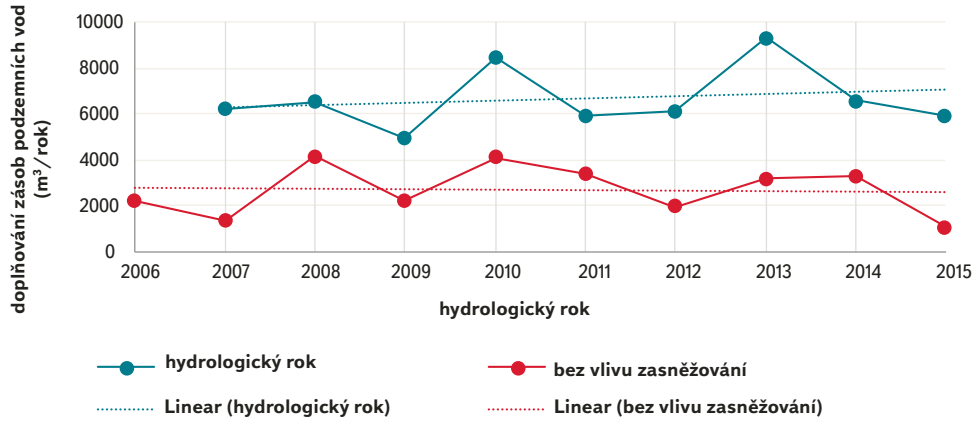

Obr. 4. Vývoj doplňování podzemních vod v letech 2005-2016

Fig. 4. Evolution of groundwater recharge in years 2005-2016

$$
a=\frac{\ln Q_{0}-\ln Q}{t}
$$

kde $\ln Q_{0}$ je prrirozený logaritmus maxima odtoku za srážkovou událost, In $Q \quad$ následné recesní minimum

t $\quad$ časové období srážkové události.

Recesní koeficient je poté dosazen do rovnice [10], na základě které je možné vypočítat efektivní infiltraci a objem vody ve zvodni:

$$
V=\frac{Q}{a}
$$

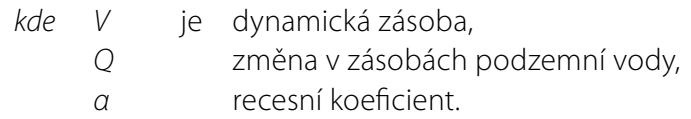

Celková efektivní infiltrace se vypočítá jako součet změn zásob během dvou srážkových událostí a objemem podzemní vody, který je při této události drénovaným pramenem.

\section{VÝSLEDKY}

\section{Povodí pramene PB0286}

Průměrné denní hodnoty podzemního odtoku za roky 2006-2015 jsou v rozmezí od 0,035 mm/den po 4,02 mm/den, což jsou poměrně vysoké hodnoty. Navíc tyto hodnoty vykazovaly vzestupnou tendenci, která je v současné době $\checkmark$ této oblasti nepravděpodobná. Výsledné hodnoty potvrdily správnost předpokladu vlivu umělého zasněžování, vývoj trendu v průběhu let vykazuje mírně sestupnou tendenci. Hodnoty doplňování podzemních vod v letech 2006 až 2015 (obr. 4) se pohybují zhruba od 1000 m³/rok do 4000 m³/rok.

\section{Povodí Fryšávky}

Získané hodnoty ročního podzemního odtoku (efektivní infiltrace) vypočtené pro část povodí Fryšávky v letech 2006-2015 (obr. 5) vykazují zřetelnou sestupnou tendenci. Průměrné roční hodnoty efektivní infiltrace se nacházejí v rozmezí od 167,64 mm/rok do 398,78 mm/rok. V roce 2014 byla naměřena nejnižši 
II m $(x)+5$

Disis

(4)

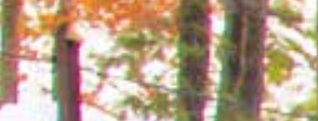

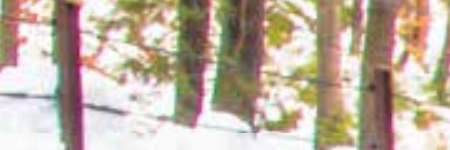

Ir visits

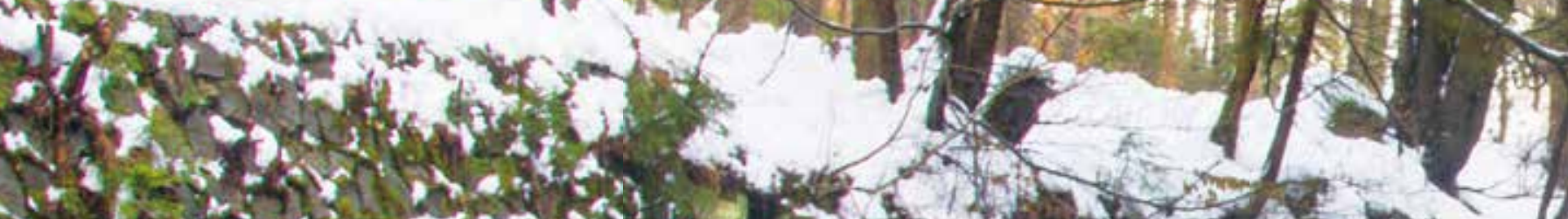

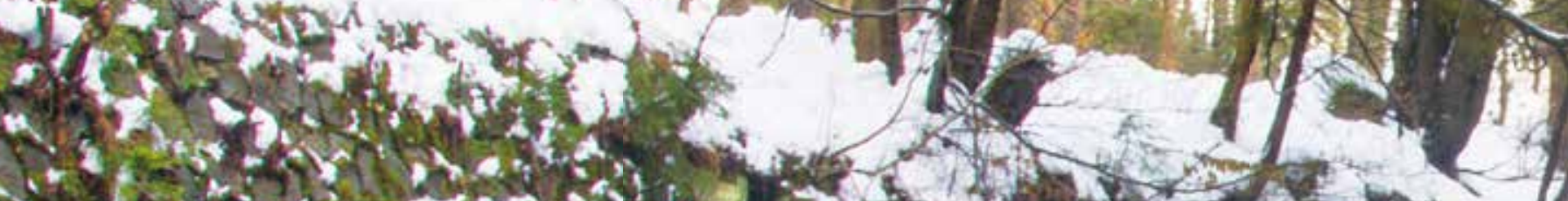

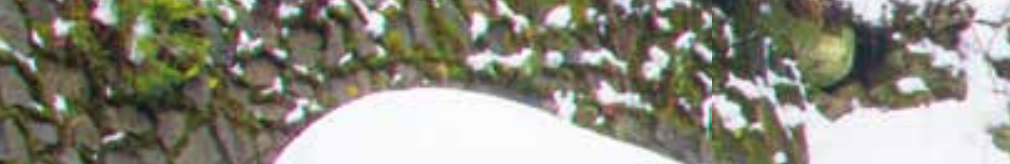

$\operatorname{lig}^{2}$

Nix:

4.5
4

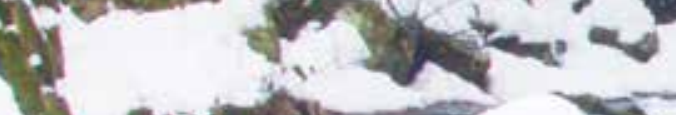

49

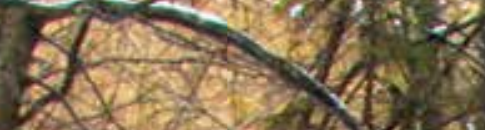

Exinges

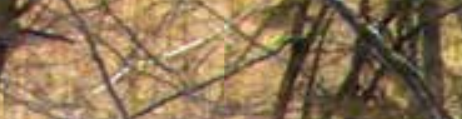

(3)

(a)

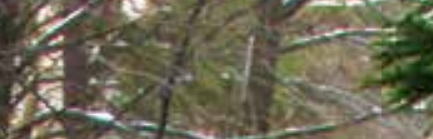

$10-5=$

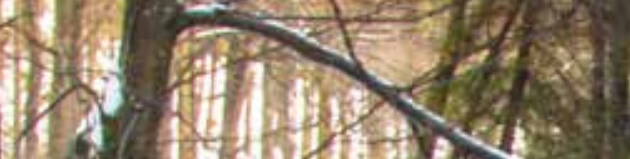

(1)

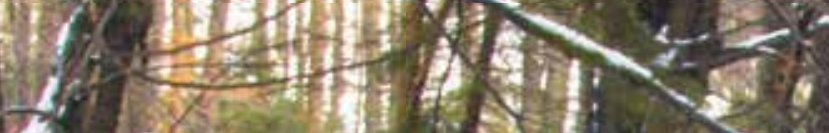

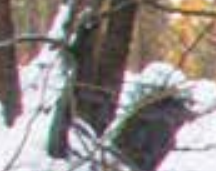

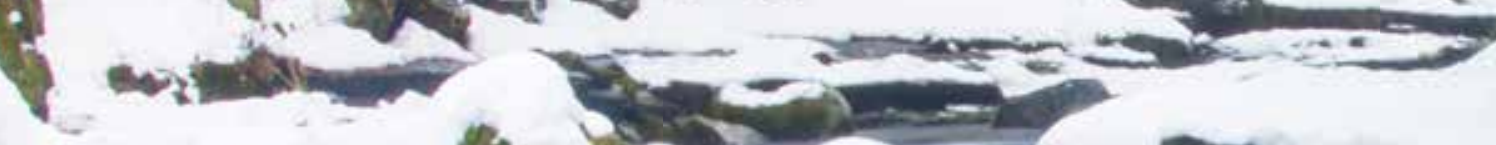

$x=20$

1

carion

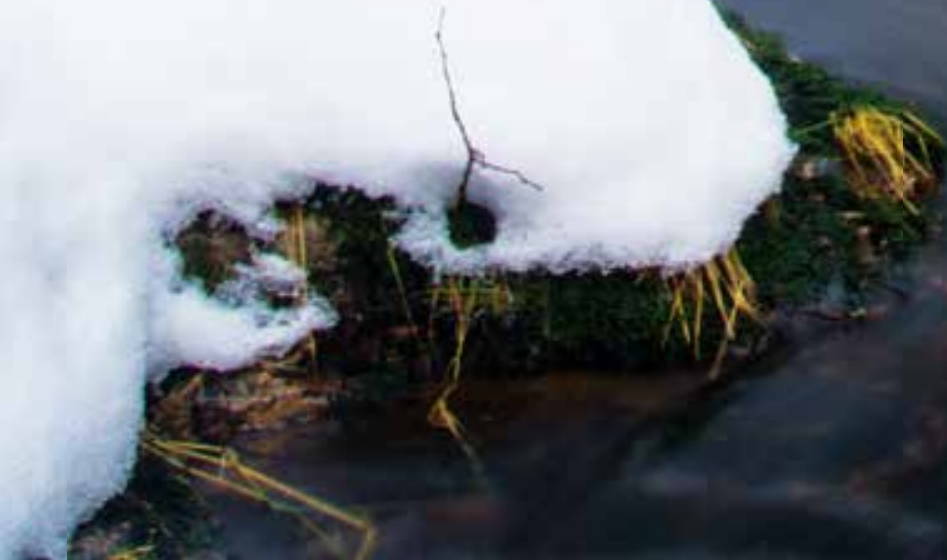




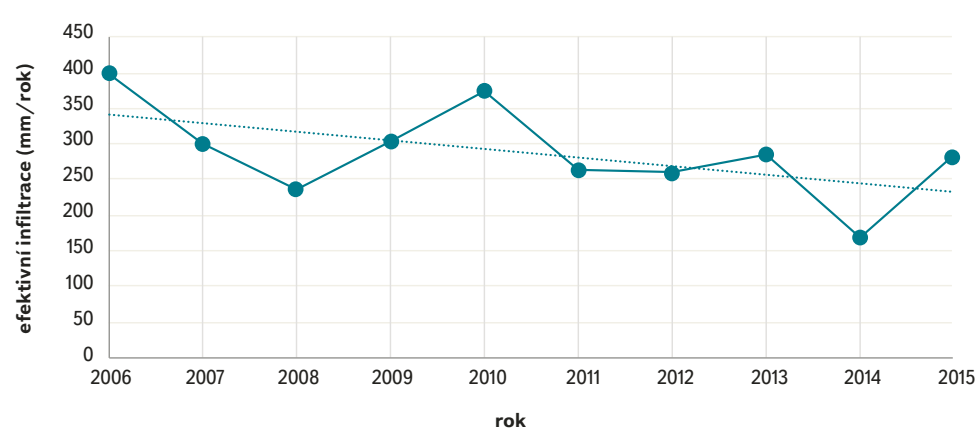

Obr. 5. Vývoj efektivní infiltrace v letech 2006-2015 (hodnoty získané z programu PART) Fig. 5. Evolution of effective inflitration in years 2006-2015 (values obtained from program PART)

hodnota, naopak v roce 2006 nejvyšší. Hodnoty podzemního odtoku se tedy od roku 2006 do roku 2015 snížily, a to o 31,43 \%. Průměrné měsíční hodnoty efektivní infiltrace (obr. 6) kolísají od nejnižších v prosinci (10,72 mm/měsíc) po nejvyšší v dubnu (47,88 mm/měsíc). Vysoké hodnoty $v$ dubnu jsou způsobeny táním sněhu a jarními srážkami, naopak nízké hodnoty v srpnu nízkou precipitací a suchem. Trend vývoje průměrných hodnot je v průběhu roku také sestupný.

Pro povodí Fryšávky bylo dále vypočteno procento srážek, které tvořilo podzemní odtok. Výsledné hodnoty však dosahovaly až $55 \%$. Takto vysoké procentuální zastoupení srážek v podzemním odtoku je nepravděpodobné. Pro tento výpočet byla použita data o srážkových úhrnech pro kraj Vysočina, jehož průměrná nadmořská výška je okolo 400-500 m n. m. Výsledná procenta mohou být tedy pouze orientační, jelikož nejvyšší část povodí Fryšávky dosahuje až 750 m n. m. Je totiž nutné vzít v úvahu tzv. srážkový gradient [4], který předpokládá, že s nárůstem nadmořské výšky o 100 m se srážkové úhrny zvyšují zhruba o $40-60 \mathrm{~mm}$.

\section{DISKUSE}

U povodí pramene PB0286, Ski I, Nové Město na Moravě bylo zjištěno, že v části povodí docházelo v letech 2005-2016 k zasněžování. Přesné určení zasněžované části povodí však není možné, stejně také stanovení přesného množství uměle dodané vody na toto povodí. Bylo tedy využito předpokladu, že trend by měl vyjít sestupný kvưli výslednému poklesovému trendu pro povodí Fryšávky, popisující vývoj podzemního odtoku v této oblasti. Přesné hodnoty doplňování podzemních vod v průběhu celého roku (tedy pravděpodobně s vlivem umělého zasněžování) pro povodí pramene PB0286 jsou tedy pouze orientační a dokazují, že i přes poměrně nepatrné antropogenní zásahy do režimu podzemních vod mohou vyvolat někdy více zřetelné změny. Důležité je také zmínit, že výsledné hodnoty u zkoumaných povodí jsou v porovnání s jinými povodími velmi vysoké. Napríklad hodnoty roční efektivní infiltrace za roky 1995-2005 zjištěné Kuchovským a Říčkou [2] u povodí řek Nedvědičky a Loučky v ložiskové oblasti Rožná (nacházející se zhruba 20 km od Nového Města na Moravě) se u obou povodí pohybují v rozmezí zhruba od $88 \mathrm{~mm} /$ rok do $260 \mathrm{~mm} /$ rok. Průměrné roční hodnoty efektivní infiltrace pro Fryšávku se nacházejí v rozmezí od 167,64 mm/rok do 398,78 mm/rok. Hodnoty jsou tedy zřetelně vyšší. Zajímavé však je, že plocha zkoumaného povodí Nedvědičky je téměř třikrát větší $\left(56,8 \mathrm{~km}^{2}\right)$ a plocha zkoumaného povodí Loučky je dokonce zhruba desetkrát větší $\left(222 \mathrm{~km}^{2}\right)$. Lze tedy pozorovat opravdu výrazný rozdíl $v$ hodnotách roční efektivní infiltrace, i přesto, že se ložisková oblast Rožná nachází nedaleko od zkoumané zájmové oblasti v podobných horninových podmínkách. Tyto vysoké hodnoty u povodí Fryšávky lze přičíst vyšší nadmořské výšce a velmi dobré retenci vod v této oblasti zpưsobené zejména tím, že na většině území

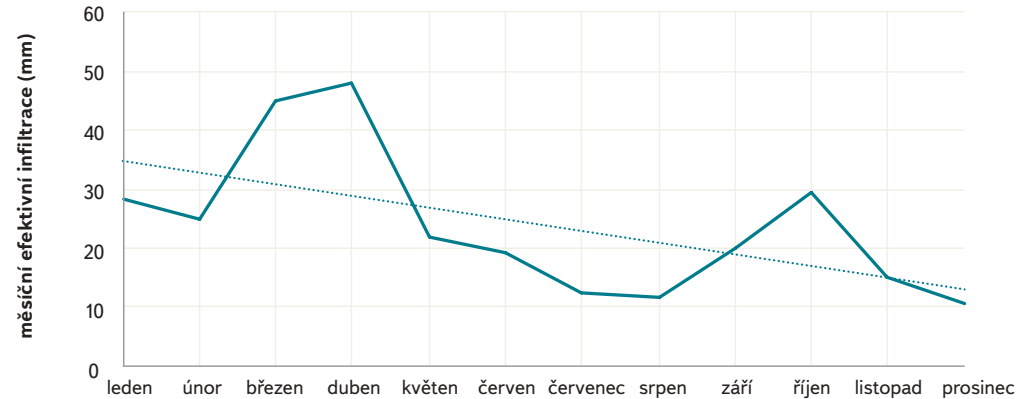

Obr. 6. Vývoj průměrné měsíční efektivní infiltrace (hodnoty získané v programu PART) Fig. 6. Evolution of average month values of effective infiltration (values obtained from program PART)

jsou především lesy (více než 50 \%), dále pak traviny, orná půda, louky a pastviny [11]. Negativní antropogenní vlivy na retenci vod jsou $v$ této oblasti minimální. U pramene PB0286 nebylo možné vypočítat hodnoty efektivní infiltrace kvůli vlivu zasněžování, už z hodnot vydatností lze však odvodit, že pramen je i přes velmi malou plochu povodí velmi silný. Průměrné hodnoty průtoků jsou shodné s některými prameny, které mají desetkrát větší povodí. Příčina těchto taktéž vysokých hodnot je opět ve velmi dobré retenci krajiny v povodí a vyšší topografické poloze.

\section{ZÁVĚR}

Cílem tohoto výzkumu bylo zhodnotit vývoj podzemního odtoku v letech 2006-2015. Tento cíl se i přes mírné komplikace (zejména u zkoumaného pramene) podařilo naplnit. U Fryšávky proběhlo zhodnocení bez větších problémů, jelikož v povodí tohoto toku nedocházelo k žádným zásadním antropogenním či jiným vlivům, které by ovlivnily výsledné hodnoty. U pramene PB0286 bylo zhodnocení ztíženo vlivem umělého zasněžování části jeho povodí. Vývoj hodnot podzemního odtoku z části Českomoravské vrchoviny vykazuje sestupnou tendenci, která je $v$ prípadě Fryšávky patrnější než u pramene PB0286. Tento nepříznivý vývoj je způsoben zejména snižujícími se srážkovými úhrny. Tato klimatická situace má samozřejmě negativní dopad na doplňování podzemních vod i v poměrně výrazně príznivých podmínkách s vyšší nadmořskou výškou a velmi dobrou retencí, kterými disponuje oblast CHKO - Ždárské vrchy. 


\section{Literatura}

[1] HRKAL, Z., MILICKÝ, M., and TESAř, M. Climate change in Central Europe and the sensitivity of the hard rock aquifer in the Bohemian Massif to decline of recharge: case study from the Bohemian Massif. Environmental Earth Sciences, 2009, vol. 59, No. 3, p. 703-713. ISSN 1866-6280.

[2] ŘíČKA, A. a KUCHOVSKÝ, T. Určení efektivní infiltrace a její prostorová a časová proměnlivost v ložiskové oblasti Rožná, Česká republika. In: 10. Česko-Slovenský mezinárodní hydrogeologický kongres, Voda - strategická surovina pro 21. století. Sborník. Ostrava: VŠB - Technická univerzita Ostrava, 2009 s. 217-220. ISBN 978-80-248-2026-2.

[3] MíSAR̆, Z. a kol. Geologie ČSSR I, Český masiv. SPN Praha, 1983.

[4] KŘriž, H. Hydrologie podzemnich vod. Praha: Academia, 1983.

[5] MAILLET, E. Essais d'hydraulique souterraine et fluviale. Libraire Sci. Paris: A Hermann, 1905, 218 p.

[6] RUTLEDGE, A.T. Computer programs for describing the recession of ground-water discharge and for estimating mean ground-water recharge and discharge from streamflow data - update. Virginia: U.S. Geological Survey, 1998, 43 p.

[7] RORABAUGH, M.I. Estimating changes in bank storage and ground-water contribution to streamflow. International Association of Scientific Hydrology, 1964, No. 63, p. 432-441.

[8] LINSLEY, R.K., KOHLER, M.A., and PAULHUS, J.L.H. Hydrology for engineers, 3rd ed. New York: McGraw Hill, 1982. ISBN 1-566-706-106.

[9] BOUSSINESQ, J. Recherches the'oriques sur l'e'coulement des nappes d'eau infiltre'es dans le sol et sur le de'bit des sources. J. Math. Pure Appl., 1904, No. 10, p. 5-78.

[10] MIJATOVIC, B. A method of studying the hydrodynamic regime of karst aquifers by analysis of the discharge curve and level fluctuation during recessio. Beograd: Institute for Geological and Geophysical research, 1970.

[11] MAŠlČEK, T. Retenční potenciál povodi řeky Fryšávky. Disertační práce. Brno: Mendelova univerzita $\checkmark$ Brně, Ústav aplikované a krajiné ekologie, 2010.

\section{Autor}

\section{Radek Chmelar̆}

凶radek.chmelar@post.cz

Ústav geologických věd, Př́rodovědecká fakulta, Masarykova univerzita

Příspěvek prošel lektorským řízením.

\section{BASEFLOW EVOLUTION FROM THE PART OF BOHEMIAN-MORAVIAN HIGHLANDS}

\section{CHMELAR, R.}

Department of Geological Sciences, Faculty of Science, Masaryk University

Keywords: groundwater - baseflow - groundwater recharge Bohemian-Moravian Highlands

This article is focused on evolution of baseflow from part of the BohemianMoravian Highlands. This is a topical issue and, given the current situation, is also often discussed. The problem of groundwater and its recharge is an important (not only) hydrogeological problem, as climatic conditions in recent years, especially low precipitation, have a negative impact on groundwater recharge. In order to analyze this situation and evolution, the values of groundwater recharge and baseflow were calculated from part of the Bohemian-Moravian Highlands near town Nové Město na Moravě for years 2006-2015. The catchment areas of the Fryšava River and the spring PB0286 were investigated in this thesis. Calculation of baseflow and groundwater recharge values for these different catchment areas was carried out by applying the Maillet equation and the hydrogeological program PART at the data obtained from the CHMI. Also, it was necessary to briefly describe geology, geomorphology, climatic conditions, and hydrology of the area of interest. 